\begin{tabular}{cc|c}
\hline Tar. Bil. Der. & Journal of Agricultural Sciences \\
& $\begin{array}{c}\text { Dergi web sayfası: } \\
\text { www.agri.ankara.edu.tr/dergi }\end{array}$ & Journal homepage: \\
& www.agri.ankara.edu.tr/journal
\end{tabular}

\title{
Hook Selectivity for Bluefish (Pomatomus saltatrix Linneaus, 1766) in Gallipoli Peninsula and Çanakkale Strait (Northern Aegean Sea, Turkey)
}

\author{
Alkan ÖZTEKİN ${ }^{\mathrm{a}}$, Adnan AYAZa, Uğur ÖZEKINCİ ${ }^{\mathrm{a}}$, Can Ali KUMOVA \\ ${ }^{a}$ Çanakkale Onsekiz Mart University, Faculty of Marine Science and Technology, Çanakkale, TURKEY \\ ${ }^{\boldsymbol{b}}$ Republic of Turkey, Ministry of Food, Agriculture and Livestock, Urla District Directorate, İmir, TURKEY
}

\section{ARTICLE INFO}

Research Article $\quad$ DOI: 10.15832/ankutbd.446380

Corresponding Author: Alkan ÖZTEKIN, E-mail: alkanoztekin@hotmail.com, Tel: +90 (286) 2180018

Received: 27 June 2014, Received in Revised Form: 22 June 2016, Accepted: 23 June 2016

\begin{abstract}
This study was conducted to determine the selectivity of the hooks used for bluefish (Pomatomus saltatrix Linneaus, 1766) in the Gallipoli Peninsula and the Dardanelles between 2006 and 2009 fishing seasons (November to September). Bluefish were fished with hooks sized 1, 1/0,2/0, 3/0, 4/0 and in sum; 1210 bluefish were caught. The hook no 2/0 caught the highest number of fish (344 fish, 20.43\%) and the hook no 1 caught the least ( 35 fish, 2.89\%). Length frequency distribution of bluefish, which were caught with different hook sizes, was used in SELECT method and according to the results; the normal scale model gave the best fit for selectivity. The normal scale model was used to calculate model length (ML) and spread value (SV) of each hook size. Model length and spread value were found as follows; $19.18 \mathrm{~cm}$ ML and 4.44 SV for hook no. 1; $21.88 \mathrm{~cm} \mathrm{ML,} \mathrm{5.07} \mathrm{SV} \mathrm{for} \mathrm{hook} \mathrm{no} \mathrm{1/0;} 24.14 \mathrm{~cm} \mathrm{ML,} \mathrm{5.59} \mathrm{SV} \mathrm{for} \mathrm{hook} \mathrm{no.} \mathrm{2/0;} \mathrm{27.02}$ $\mathrm{cm}$ ML, 6.26 SV for hook no. 3/0; $28.19 \mathrm{~cm} \mathrm{ML,} \mathrm{6.53} \mathrm{SV} \mathrm{for} \mathrm{hook} \mathrm{no.} \mathrm{4/0,} \mathrm{respectively.} \mathrm{Because} \mathrm{the} \mathrm{minimum} \mathrm{landing}$ size (MLS) for bluefish has been stipulated as $20.0 \mathrm{~cm}$ (TL) in the Turkish Fishery Regulations, the use of hook no. 2/0 or bigger hook sizes can be recommended for fishing of bluefish.
\end{abstract}

Keywords: Bluefish; Çanakkale Strait; Hook selectivity; SELECT method

\section{Gelibolu Yarımadası ve Çanakkale Boğazı’nda (Kuzey Ege Denizi, Türkiye) Lüfer Balığı için (Pomatomus saltatrix Linneaus, 1766) İğne Seçiciliği}

\section{ESER BILGISİ}

Araştırma Makalesi

Sorumlu Yazar: Alkan ÖZTEKIN, E-posta: alkanoztekin@hotmail.com, Tel: +90 (286) 2180018

Geliş Tarihi: 27 Haziran 2014, Düzeltmelerin Gelişi: 22 Haziran 2016, Kabul: 23 Haziran 2016

\section{ÖZET}

Bu çalışma, Gelibolu Yarımadası ve Çanakkale Boğazı'ndaki lüfer balığı (Pomatomus saltatrix Linnaeus, 1766) avcılığında kullanılan olta iğneleri seçiciliklerini belirlemek için, 2006-2009 balıkçılık sezonunda, lüfer göç zamanı 
olan Eylül, Ekim ve Kasım ayları arasında gerçekleştirilmiştir. Lüfer balıklarının avcılığı 1, 1/0, 2/0, 3/0, 4/0 numara iğneler ile gerçekleştirilmiş ve 1210 adet lüfer balığı yakalanmıştır. En fazla birey 2/0 numara iğne ile (344 birey, \% 20,43) en az birey ise 1 numaralı iğne ile (35 birey, \% 2,89) elde edilmiştir. Farklı iğne numaraları ile avlanan lüfer balığının boy frekans dağılımları kullanılarak uygulanan SELECT metoduna göre en uygun model, normal scale model olarak saptanmıştır. Normal scale modele göre kullanılan iğne büyüklükleri için hesaplanan optimum yakalama boyları (OYB) ve eğrinin genişlikleri (EG), sırasıyla, 1 no'lu iğne için 19,18 cm OYB ve 4,44 EG; 1/0 no'lu iğne için 21,88 cm OYB ve 5,07 EG; 2/0 no'lu iğne için 24,14 cm OYB ve 5,59 EG; 3/0 no'lu iğne için 27,02 cm OYB ve 6,26 EG ve 4/0 no'lu iğne için 28,19 cm OYB ve 6,53 EG'dir. Lüfer balıklarının Türkiye'deki minimum avlanma boyu $20 \mathrm{~cm}$ olduğu için lüfer avcılığında 2/0 numara ve daha büyük iğnelerin kullanımı önerilebilir.

Anahtar Kelimeler: Lüfer balığı; Çanakkale Boğazı; İğne seçiciliği; SELECT yöntem

(C) Ankara Üniversitesi Ziraat Fakültesi

\section{Introduction}

In fisheries management, knowledge of size selectivity can be used for the estimation of incidental mortality (i.e. mortality of discards and escapees); yield-per-recruit analysis; age and lengthbased population models; estimation of population length frequencies; length at age (Millar \& Fryer 1999). Therefore, the estimations of size selectivity of fishing gears offer remarkable information for the conservation and optimum exploitation of fisheries resources (Beverton \& Holt 1957; Hilborn \& Walters 1992; Quinn \& Deriso 1999). Although the size selectivity of fishing gears such as trawls and gill nets is well known, there is still a gap between the size selection curves of hand lines. Not only logistic type models, typically used to describe the selectivity of trawls, but also unimodal models used in gillnet selectivity studies have been used in hook selectivity studies (Clark 1960; Erzini et al 1996; 1998; 2006), (Millar \& Holst 1997; Sousa et al 1999; Czerwinski et al 2010; Campbell et al 2014; Öztekin et al 2014; Ateşşahin et al 2015).

Bluefish (Pomatomus saltatrix) is a migrant species, which has wide geographical distribution, except for the northern and central-Pacific Ocean (Briggs 1960; Wilk 1977). It is also one of the most important commercial fish species in Turkey, and particularly fished during alimental and spawning migration between the Black Sea and Aegean Sea. Fishing activity is intensive, especially due to purse seine, trawling net, hand lines, encircling gill and trammel net (Ceyhan \& Akyol 2005; Acarlı et al
2013). The production made in Turkey is observed to have risen to one-third of the world's production during some years (Ceyhan \& Akyol 2006). Unfortunately, recently, bluefish population has shown substantial declines (Robillard et al 2009) and some researchers (Akyol \& Ceyhan 2007; Özdemir et al 2009) reported over-fishing pressure on the species. For these reasons, in some countries like Brazil, Australia and Tunisia, the fishing of bluefish was subjected to some regulations in order to allow the proper management of this resource (Dhieb et al 2006). In Turkey, although current stock levels are uncertain, there are indications (i.e. smaller average sizes of individuals, lower catch per unit effort according to the years) of the fact that stocks have declined due to fishing pressure. Recently, there has been much discussion concerning the state of bluefish stocks, because of declining catches (Acarlı et al 2013).

Although, a great deal of research has been published on the biology of this species (Lassiter 1962; Conand 1975; Van der Elst 1976; Champagnat 1983; Krug \& Haimovici 1989; Barger 1990; Graves et al 1992; Haimovici \& Krug 1992; Terceiro \& Ross 1993; Lucena \& O’Brien 2001; Salerno et al 2001; Sipe \& Chittenden 2002; Ceyhan et al 2007; Cengiz et al 2012), there is no information about the selectivity of the hooks used for bluefish all over the world. This study aims to determine the selectivity of hooks sized $1,1 / 0,2 / 0,3 / 0$ and $4 / 0$ used for bluefish in the Gallipoli Peninsula and the Dardanelles. 


\section{Material and Methods}

\subsection{Study area}

The Çanakkale Strait is a strategic natural transition point where pelagic fish populations migrate from the Black Sea to the Aegean and the Mediterranean Sea and in the opposite direction for the purposes of feeding and reproduction. In this bi-directional pass along the Dardanelles during certain periods of the year, migratory fish schools are very important fishing potentials for small coastal fishermen and big coastal fishing boats. Atlantic mackerel Scomber scombrus (Linnaeus 1758), chub mackerel Scomber japonicus (Houttuyn 1782), bluefish and horse mackerel Trachurus trachurus (Linnaeus 1758) which are also known as Migratory Fish species are intensively fished during the period from early September to late February known as winter fishery and the whole summertime (Ünsal 2010). Therefore, the Çanakkale Strait has a special importance for the coastal fishery of Turkey (Zengin 2013).

Bluefish samples were collected between 2006 and 2009 fishing seasons (November to September) from the Çanakkale Strait, at depths ranging from 1 $\mathrm{m}$ to $40 \mathrm{~m}$ (Figure 1).

Fishing lines and hook sizes used in the present study were designated in accordance with those of fishermen. Fishing lines for bluefish were used in the study and all the lines had the same features except for hook sizes. Leaders with $150 \mathrm{~cm}$ length and $0.4 \mathrm{~mm}$ diameter which were equipped with hooks between no. 2 and 4 were knotted to $0.6 \mathrm{~mm}$ diameter main line with swivels. Hooks were equipped to with 10 $\mathrm{cm}$ long leaders between two swivels for flexibility in currents. Hooks were tied to $120 \mathrm{~cm}$ long lines and each hook was interspaced in about $3 \mathrm{~cm}$. Hooks sized 13 were used with every fishing tackle. Straight shank hooks (Mustad 3282) sized 1, 1/0, 2/0, 3/0 and $4 / 0$ were determined for main hooks and then equipped together with hooks sized 13 (Figure 2).

By virtue of bluefish's predatory behaviors, hooks were used along with live bait. The round sardinella (Sardinella aurita Valenciennes 1847), big-scale sand smelt and blotched picarel (Spicara maena Linnaeus 1758) were used as baits. Different baits were used since bluefish were attracted to different kinds of

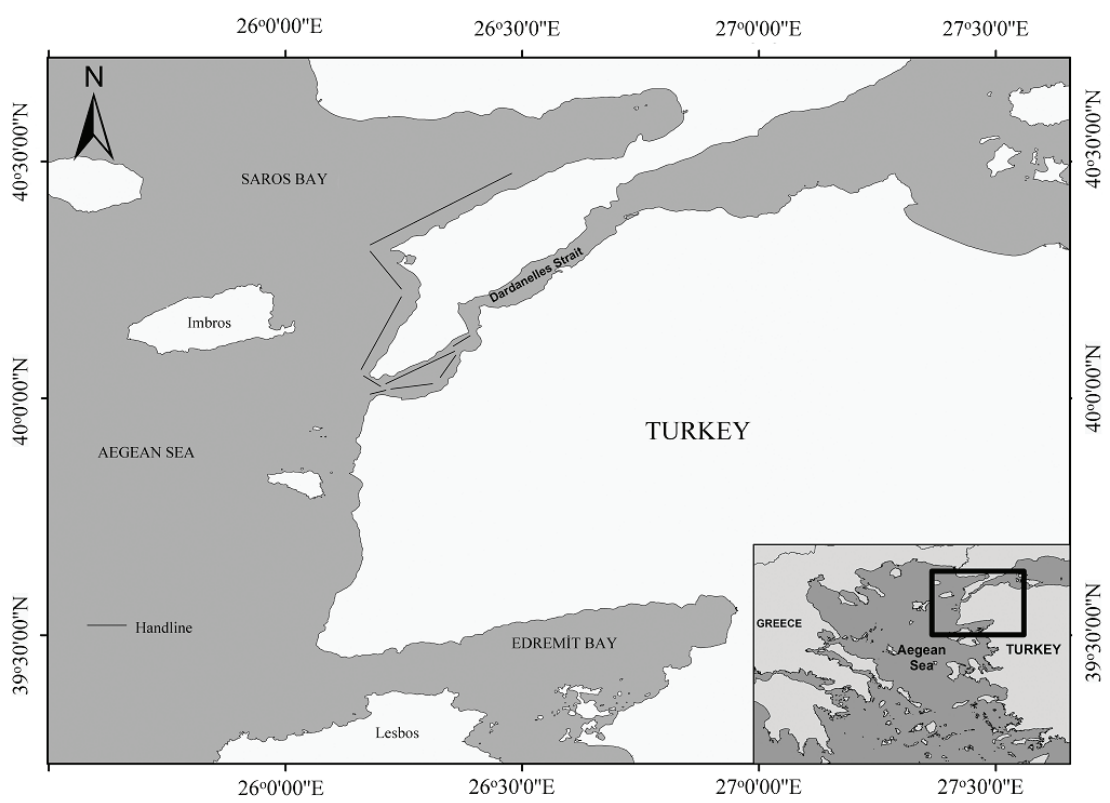

Figure 1- Study area (Northern Aegean Sea, Turkey) 


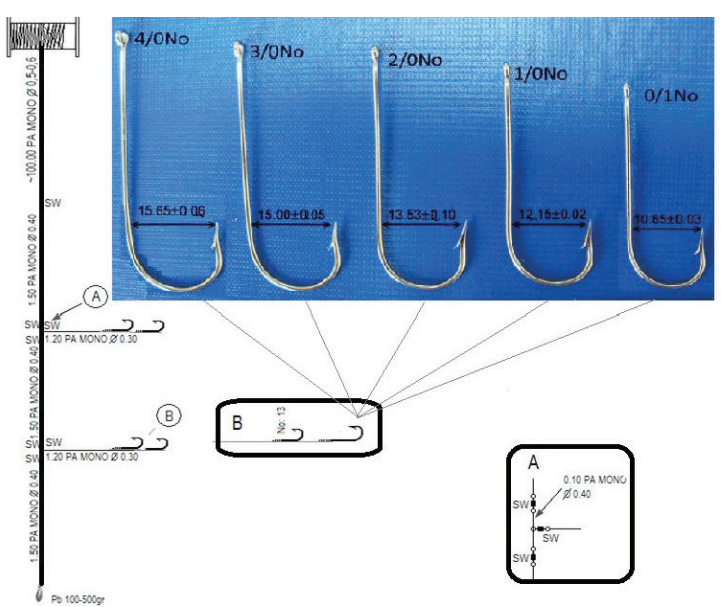

Figure 2- Hooks used for fishing bluefish and gap measures (cm) (hook gaps were determined by calculating the mean value of the gap between 60 hooks in each box)

baits in a day time. During fishing, only one type of bait was used not to affect catching efficiency. Due to their higher efficiency during daytime, live baits were preferred for sampling. However, sardine was also used as bait in case of an absence of live baits. Five fishing tackles were set with the same specifications; yet with different hook sizes differring between size $1,1 / 0,2 / 0,3 / 0$ and $4 / 0$, respectively. The period was required for fishing bluefish with line differs between 5 to 10 minutes. The position of bait on hook does not affect the period. Fishing tackles were used alternatively to prevent the lack of fishing efficiency caused by fishermen, every 60 minutes. Samples were measured to the nearest $\mathrm{cm}$ (total length) and fish mouth gaps were measured during selectivity studies with $0.01 \mathrm{~mm}$ precised digital caliper to determine whether there is a relation between mouth gaps and hook sizes.

SELECT (select each length class' catch total) method was used to evaluate the data related to fish hooks (Millar 1992). This method assumes that the number of fish having length $l$ and caught with a hook sized $j$ has a $n_{l j}$ Poisson distribution, and is defined by Equation 1 .

$\mathrm{n}_{l j} \approx \mathrm{n}_{l j} \approx$ Pois $\left(p_{j} \lambda_{l} r_{j}(l)\right)$
Where; $\lambda$, abundance of fish sized $l$ and caught by hook; $p_{j}(1)$, relative fishing intensity (the relative abundance of fish sized $l$ that hook sized $j$ can catch). The Poisson distribution of the number of fish sized $l$ and caught by fishing gear having hook sized $j$ is defined as $p_{j(l)} \lambda_{l} . r_{j(l)}$ is the selectivity curve for the hook sized $j$.

Log-likelihood of $l_{j}$ is expressed as Equation 2.

$\sum_{l} \sum_{j}\left\{n_{l} \log \left[p_{j} \lambda_{l} r_{j}(l)\right]-p_{j} \lambda_{l} r_{j}(l)\right\}$

Gillnet (generalized including log-linear $\mathrm{N}$ estimation technique) program (Constant 1998) was used for the analysis of the obtained data. The program calculates the selectivity parameters of five different models based on the SELECT method and by comparing the model deviances; the lowest one is chosen for the best model (Millar \& Holst 1997; Millar \& Fryer 1999). The equations used in the SELECT models are as follows.

Normal location (Equation 3).

$\exp \left(-\frac{\left(L-k \cdot m_{j}\right)^{2}}{2 \sigma^{2}}\right)$

Normal scale (Equation 4).

$\exp \left(-\frac{\left(L-k_{1} \cdot m_{j}\right)^{2}}{2 k_{2}^{2} \cdot m_{j}^{2}}\right)$

Log-normal (Equation 5).

$\frac{1}{L} \exp \left(\mu+\log \left(\frac{m_{j}}{m_{1}}\right)-\frac{\sigma^{2}}{2}-\frac{\left(\log (L)-\mu-\log \left(\frac{m_{j}}{m_{1}}\right)\right)^{2}}{2 \sigma^{2}}\right)$

Gamma (Equation 6).

$\left(\frac{L}{(\alpha-1) \cdot k \cdot m_{j}}\right)^{\alpha-1} \exp \left(\alpha-1-\frac{L}{k \cdot m_{j}}\right)$

Bi-normal (Equation 7).

$\exp \left(-\frac{\left(L-k_{1} \cdot m_{j}\right)^{2}}{2 k_{2}^{2} \cdot m_{j}^{2}}\right)+c \cdot \exp \left(-\frac{\left(L-k_{3} \cdot m_{j}\right)^{2}}{2 k_{4}^{2} \cdot m_{j}^{2}}\right)$ 
The Kolmogorov-Smirnov (K-S) test was used to determine differences between size frequency distributions of fish caught by hooks in various sizes (Sigeal \& Castellan 1989; Karakulak \& Erk 2008).

\section{Results and Discussion}

The field studies were carried out with hooks sized $1,1 / 0,2 / 0,3 / 0,4 / 0$ and a total of 1210 samples were caught during these studies. In terms of hook sizes, the highest number of bluefish were caught with hook no. 2/0 (344 fish, 20.43\%) and the least bluefish were caught with hook no. 1 ( 35 fish, $2.89 \%$ ). The number of bluefish caught by each differently sized hook and minimum, maximum, mean lengths and standart error are displayed in Table 1.

Table 1- The numbers and length values of bluefish according to hook sizes

\begin{tabular}{crrrrr}
\hline Hook & & & \multicolumn{3}{c}{ Total length $(\mathrm{cm})$} \\
\cline { 3 - 6 } numbers & $n$ & $\%$ & Minimum & Maximum & Mean \pm S.E. \\
\hline 1 & 35 & 2.89 & 19.5 & 24.1 & $21.74 \pm 0.16$ \\
$1 / 0$ & 313 & 25.87 & 14.9 & 36.5 & $23.05 \pm 0.22$ \\
$2 / 0$ & 344 & 28.43 & 13.8 & 45.2 & $22.18 \pm 0.28$ \\
$3 / 0$ & 301 & 24.88 & 14.8 & 41.9 & $27.78 \pm 0.28$ \\
$4 / 0$ & 217 & 17.93 & 20.5 & 49.0 & $30.33 \pm 0.33$ \\
\hline
\end{tabular}

S.E, standart error

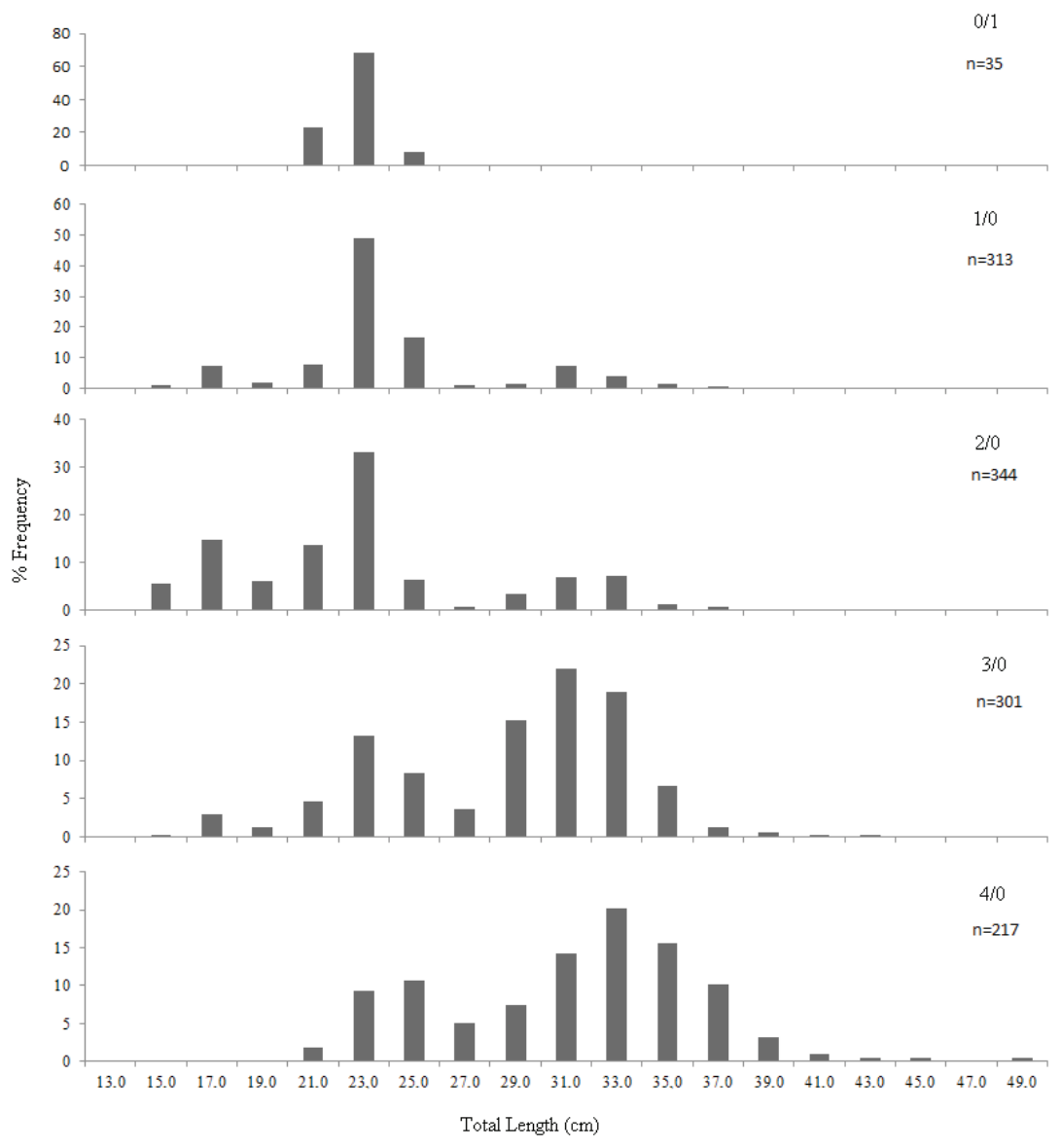

Figure 3 - Length frequency distribution of Bluefish (Pomatomus saltatrix Linnaeus, 1766) for each hook size 
The catch size-frequency distributions are given in Figure 3 for each hook size used for fishing bluefish. Larger hook sizes have the greater mean length of the captured fish.

The length frequency distributions of the bluefish caught by the 5 different hook sizes (all hook sizes combined) were significantly different, except for the combination of hooks sized 1-1/0 (Table 2).

The normal scale model with the lowest deviance was given the best fit in comparison to the deviances of five models of SELECT (Table 3).

According to the normal scale model, the modal lengths and spread values of bluefish for each hook size are presented in Table 4. Model length accurately increases as the hook number increases.

Table 4- Modal lengths and spread value of bluefish for each hook size according to the normal scale model

\begin{tabular}{ccc}
\hline Hook numbers & $\begin{array}{c}\text { Model length } \\
(\mathrm{cm})\end{array}$ & $\begin{array}{c}\text { Spread value } \\
(\mathrm{cm})\end{array}$ \\
\hline 1 & 19.18 & 4.44 \\
$1 / 0$ & 21.88 & 5.07 \\
$2 / 0$ & 24.14 & 5.59 \\
$3 / 0$ & 27.02 & 6.26 \\
$4 / 0$ & 28.19 & 6.53 \\
\hline
\end{tabular}

Table 2- Results of the Kolmogorov-Smirnov test

\begin{tabular}{ccccl}
\hline & & \multicolumn{3}{c}{ Kolmogorov-Smirnov test } \\
\cline { 2 - 5 } Hook numbers & Hook numbers & D max & Critical values & Decision \\
\hline 1 & $1 / 0$ & 0.102 & 0.242 & $\mathrm{H}_{0}$ Not Reject \\
1 & $2 / 0$ & 0.265 & 0.241 & $\mathrm{H}_{0}$ Reject \\
1 & $3 / 0$ & 0.691 & 0.243 & $\mathrm{H}_{0}$ Reject \\
1 & $4 / 0$ & 0.804 & 0.248 & $\mathrm{H}_{0}$ Reject \\
$1 / 0$ & $2 / 0$ & 0.219 & 0.106 & $\mathrm{H}_{0}$ Reject \\
$1 / 0$ & $3 / 0$ & 0.528 & 0.110 & $\mathrm{H}_{0}$ Reject \\
$1 / 0$ & $4 / 0$ & 0.620 & 0.120 & $\mathrm{H}_{0}$ Reject \\
$2 / 0$ & $3 / 0$ & 0.507 & 0.107 & $\mathrm{H}_{0}$ Reject \\
$2 / 0$ & $4 / 0$ & 0.622 & 0.118 & $\mathrm{H}_{0}$ Reject \\
$3 / 0$ & $4 / 0$ & 0.234 & 0.121 & $\mathrm{H}_{0}$ Reject \\
\hline
\end{tabular}

$\overline{\mathrm{H}_{0}}$, there are no significant differences between length frequency distribution $(\alpha=0.05, \mathrm{~K}=1.36)$

Table 3- The SELECT model parameters estimates for hook selectivity

\begin{tabular}{llcccccc}
\hline \multirow{2}{*}{ Model } & \multicolumn{3}{c}{ Equal fishing powers } & \multicolumn{3}{c}{ Fishing power $\alpha$ hook size } \\
\cline { 2 - 7 } & Parameters & $\begin{array}{c}\text { Modal } \\
\text { deviance }\end{array}$ & $p$ & Parameters & $\begin{array}{c}\text { Modal } \\
\text { deviance }\end{array}$ & $\begin{array}{c}\text { Degree of } \\
\text { freedom }\end{array}$ \\
\hline Normal location & $\begin{array}{l}\mathrm{k}=1.765 \pm 0.021 \\
\sigma=5.112 \pm 0.158\end{array}$ & 565.99 & $0.0000 \begin{array}{l}\mathrm{k}=1.849 \pm 0.021 \\
\sigma=5.222 \pm 0.163\end{array}$ & 561.62 & 0.0000 & 70 \\
\hline Normal scale & $\begin{array}{l}\mathrm{k} 1=1.801 \pm 0.025 \\
\mathrm{k} 2=0.417 \pm 0.015\end{array}$ & 561.88 & 0.0000 & $\begin{array}{l}\mathrm{k} 1=1.896 \pm 0.022 \\
\mathrm{k} 2=0.407 \pm 0.014\end{array}$ & 561.83 & 0.0000 & 70 \\
\hline Gamma & $\begin{array}{l}\alpha=20.902 \pm 1.442 \\
\mathrm{k}=0.087 \pm 0.005\end{array}$ & 573.69 & 0.0000 & $\begin{array}{l}\alpha=21.902 \pm 1.423 \\
\mathrm{k}=0.087 \pm 0.005\end{array}$ & 573.69 & 0.0000 & 70 \\
\hline Log normal & $\begin{array}{l}\mu 1=2.949 \pm 0.012 \\
\sigma=0.220 \pm 0.007\end{array}$ & 590.37 & 0.0000 & $\begin{array}{l}\mu 1=2.998 \pm 0.011 \\
\sigma=0.220 \pm 0.007\end{array}$ & 590.37 & 0.0000 & 70 \\
\hline Bi-normal & not calculated & - & - & not calculated & - & - & - \\
\hline
\end{tabular}


The selectivity curves of bluefish for each hook size according to the normal scale model are presented in Figure 4.

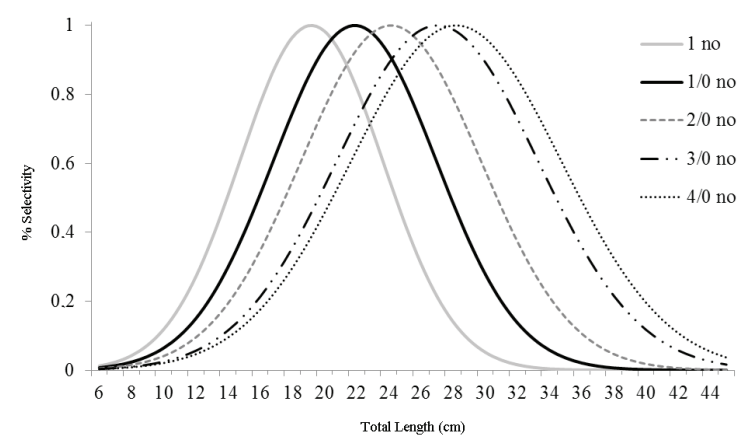

Figure 4- The selectivity curves of bluefish for each hook size according to the normal scale model

Due to the Turkish Fishery Regulation (TFR 2012); the minimum landing size of the bluefish is $20 \mathrm{~cm}$. The hooks used in this study was highly selective and had no pressure on bluefish stocks except for the hook sized 1 according to the model length $(\mathrm{cm})$ given in Table 4.

To ensure sustainable improvements in fisheries management, regulations on specific fishing gears must be put in order correspondingly with selectivity studies. The normal scale model gave the best fit for the data obtained in this study. It has been observed that estimated model lengths were increasing in parallel with the increase in hook sizes.

Hook and bait are the main factors that affect catching efficiency when fishing is conducted with line (Kaykaç et al 2003). Some particular studies reported that hook size does not have a significant effect on selectivity (Bertrand 1988; Clarke et al 2001). This conclusion is derived from the fact that bigger fish have bigger mouth gaps. On the other hand, some other studies reported that hook size has an effect on selectivity. Considering both of these facts, it is determined that smaller hook size catches smaller fish and bigger hook size catches bigger fish (Cortez-Zaragoza et al 1989; Otway \& Craig 1993; Grixti et al 2007). In the present study; hooks sized 4/0 caught the largest fish size group with the length of $49 \mathrm{~cm}$ while hooks sized 2/0 caught the second largest fish size group with the length of $45.2 \mathrm{~cm}$. This partially indicates resemblance with previous studies. Hook size and type that will be used on lines have significant importance on the resemblance of fishing efforts.

Erzini et al (1998) stated that increasing the size of hook used on lines causes lower fish catching numbers. On the contrary, our results showed that the hook size $4 / 0$, which is the biggest size, had the largest number of fish caught with 217 individuals while the smallest hook sized 1 caught 35 individuals. This difference occurred due to the consideration of different species. Bjordal (1981) reported that small sized hooks have higher catching efficiency compared to bigger sized hooks. The results obtained in this study, except for the hook sized 1 , are mostly in accordance with alternate studies.

\section{Conclusions}

An efficient management strategy could not apply for bluefish population spreading over Turkey until nowadays. Fishing gears must be improved for the preservation of fish stocks. Improving the selective features of fishing gears make a significant contribution to the preservation of natural fish stocks and to avoid catching fish with undesired length (Kalayc1 2001). More species based studies on hook sizes should be carried out to prevent catching fish under length of the first spawning due to the use of small hook size. The use of small sized hooks that catch fish under length of the first spawning must be inhibited and legislated with government laws and regulations. There are many selectivity studies on gill net or trawling but no study focused on fish hooks (Give some selectivity studies references about selectivity of other fishing methods). Woll et al (2001) stated that the methods of gill net selectivity can be applied to fish hook selectivity and that fish can be caught in nets from different parts of their bodies; yet with fishhook they can only be angled from their mouths. 
While fishing bluefish is allowed for those being longer than $30 \mathrm{~cm}$ in USA (Muller 2001). A research conducted in the Marmara Sea and the Straits in Turkey was displayed the first reproduction fork length as $25.4 \mathrm{~cm}$ for bluefish (Ceyhan et al 2007). Unfortunately, the minimum landing size (MLS) for bluefish is $20.0 \mathrm{~cm}$ (TL) in the Turkish Fishery Regulation (TFR 2012). The $20.0 \mathrm{~cm}$ length limit applied is not effective in preserving bluefish stocks. For this reason, using of hook sized $2 / 0$ or higher can be recommended. Considering the importance of the bluefish catching in Turkey's fishery, the effective precautions such as size selectivity, catching quote, fishing effort control should be implemented. Additionally, in parallel with the developments in fisheries management and studies based on selectivity; the detection of the first reproduction length of commercial fish species and the use of specific fishing gears for certain species are of great importance. Therefore, the landing of individuals under the length at first maturity can be prevented and fish stocks can be preserved.

\section{Acknowledgements}

The present study was carried out with financial support of TUBITAK (Project No: 106Y021 and 106O097). The authors thank to Cahit CEVIZ.

\section{References}

Acarlı D, Ayaz A, Özekinci U \& Öztekin A (2013). Gillnet selectivity for bluefish (Pomatamus saltatrix, L. 1766) in Çanakkale Strait, Turkey. Turkish Journal of Fisheries and Aquatic Sciences 13: 349-353

Akyol O \& Ceyhan T (2007). Exploitation and mortalities of bluefish (Pomatomus saltatrix L.) in the Sea of Marmara, Turkey. Journal of Applied Biological Sciences 1: 25-27

Ateşşahin T, Duman E \& Cilbiz M (2015). Selectivity and catch efficiency of three spinner hook sizes in angling for rainbow trout (Oncorhynchus mykiss) (Walbaum 1792) in Karakaya Dam Lake (Eastern Turkey). Turkish Journal of Fisheries and Aquatic Sciences 15: 851-859
Barger L E (1990). Age and growth of bluefish Pomatomus saltatrix from the Northern Gulf of Mexico and US South Atlantic coast. Fishery Bulletin 88: 805-809

Bertrand J (1988). Selectivity of hooks in the handline fishery of the Saya de Malha Banks (Indian Ocean). Fisheries Research 6: 249-255

Beverton J R H \& Holt S J (1957). On the Dynamics of Exploited Fish Populations. Ministry of Agriculture, Fisheries and Food. Fishery Investigation Series 2, 19, pp. 533

Bjordal A (1981). Engineering and fish reaction aspects of longlining. A review. ICES CM Documents; 1981/ B: 35

Briggs J C (1960). Fishes of world-wide (circumtropical) distribution. Copeia No. 3: 171-180

Campbell M D, Pollack A G, Driggers W B \& Hoffmayer E R (2014). Estimation of hook selectivity of red snapper and vermilion snapper from fisheryindependent surveys of natural reefs in the Northern Gulf of Mexico. Marine and Coastal Fisheries 6(1): 260-273

Cengiz Ö, Özekinci U \& Öztekin A (2012). The relationships between total lenght-otolith length of bluefish, Pomatomus saltatrix, (Linnaeus, 1766) from Gallipoli Peninsula and Dardanelles (North-eastern Mediterranean, Turkey). I ğdır University Journal of the Institute of Science and Technology 2: 31-34

Ceyhan T \& Akyol O (2005). The hand lines used in bluefish (Pomatomus saltatrix L., 1766) fishery in Marmara Region. Ege University Journal of Fisheries and Aquatic Sciences 22: 351-355

Ceyhan T \& Akyol O (2006). Age distribution and relationship between fork length and otolith length of bluefish (Pomatomus saltatrix L., 1766) in the Sea of Marmara. Ege University Journal of Fisheries and Aquatic Sciences 23: 369-372

Ceyhan T, Akyol O, Ayaz A \& Juanes F (2007). Age, growth and reproductive season of bluefish (Pomatomus saltatrix) in the Marmara Region, Turkey. ICES Journal of Marine Science 64: 531-536

Champagnat C (1983). Peche, biologie et dynamique du tassergal (Pomatomus saltatrix Linnaeus, 1766) sur les Cotes Senegalo-Mauritaniennes. Travaux et Documents du l'ORSTOM 168: 1-279

Clark J R (1960). Report on selectivity of fishing gear, In Fishing effort, and effect of fishing on resources and the selectivity of fishing gear. ICNAF Special Publication 2: 27-36 
Clarke M, Connolly P \& Bracken J (2001). Aspects of reproduction of the deep water sharks Centroscymnus coelolepis and Centrophorus squamosus from west of Ireland and Scotland. Journal of the Marine Biological Association of the United Kingdom 81(6): 1019-1029. doi: 10.1017/S0025315401005008

Conand C (1975). Maturite sexuelle et fecondité du Tassergal, Pomatomus saltator (L., 1776), PoissonsPomatomidae. Bulletin De l'Institut Fondamental d'Afrique Noire (A). 37: 395-466

Constant (1998). Gillnet software, Denmark www. Constat.dk.

Cortez-Zaragoza E, Dalzell P \& Pauly D (1989). Hook selectivity of yellowfin tuna (Thunnus albacares) caught off Darigayos Cove, La Union, Philippines. Journal of Applied Ichthyology 1: 12-17

Czerwinski I A, Gutiérrez-Estrada J C, Escofet M C S \& Hernando J A (2010). Hook selectivity models assesment for black spot seabream. Classic and heuristic approaches. Fisheries Research 102: 41-49

Dhieb K, Ghorbel M, Jarboui O \& Bouain A (2006). Interactions between reproduction and fisheries in bluefish (Pomatomus saltatrix), from Gulf of Gabes (Tunisia). Cybium 30: 355-364

Erzini K, Gonçalves J M S, Bentes L, Lino P G \& Cruz J (1996). Species and size selectivity in a Portuguese multispecies artisanal long-line fishery. Ices Journal of Marine Science 53: 811-819

Erzini K, Gonçalves J M S, Bentes L, Lino P \& Ribeiro J (1998). Species and size selectivity in a "red" sea bream longline "metier" in the Algarve (Southern Portugal). Aquatic Living Resources 11: 1-11

Erzini K, Goncalves J M S, Bentes L, Moutopoulos D K, Casal J A H, Soriguer M C, Puente E, Errazkın L A \& Stergiou K I (2006). Size selectivity of trammel nets in southern European small-scale fisheries. Fisheries Research 79: 183-201

Graves J E, McDowell J R, Beardsley A M \& Scoles D R (1992). Stock structure of the bluefish Pomatomus saltatrix along the mid-Atlantic coast. Fishery Bulletin 90: 703-710

Grixti D, Conron S D \& Jones P L (2007). The effect of hook/bait size and angling technique on the hooking location and the catch of recreationally caught black bream Acanthopagrus butcheri. Fisheries Research 84: 338-344

Haimovici M \& Krug L C (1992). Alimentação e reprodução da enchova Pomatomus saltatrix no litoral sul do Brasil. Revista Brasileira de Biologia 52: 503513

Hilborn R \& Walters C J (1992). Quantitative Fisheries Stock Assessment: Choice, Dynamics, and Uncertainty. Chapman Hall. New York. pp. 570

Kalaycı F (2001). Dip paraketasında kanca büyüklüğünün seçicilik üzerine etkisi. Yüksek lisans tezi, Ondokuz May1s Üniversitesi Fen Bilimleri Enstitüsü (Basılmamış), Samsun

Karakulak F S \& Erk H (2008). Gill net and trammel net selectivity in the northern Aegean Sea, Turkey. Scientia Marina 72(3): 527-540

Kaykaç M H, Ulaş A, Metin C \& Tosunoğlu Z (2003). Olta balıkçılığında düz ve çapraz iğnelerin av etkinliği üzerine bir araştırma. Ege Üniversitesi Su Ürünleri Dergisi 20: 227-231

Krug L C \& Haimovici M (1989). Age and growth of enchova Pomatomus saltatrix in Southern Brazil. Atlantica 11: 47-61

Lassiter R R (1962). Life history aspects of the bluefish, Pomatomus saltatrix, from the Coast of North Carolina. MSc Thesis, North Carolina State College, North Carolina

Lucena F M \& O'Brien C M (2001). Effects of the gear selectivity and different calculation methods on estimating growth parameters of bluefish, Pomatomus saltatrix (Pisces: Pomatomidae), from Southern Brazil. Fishery Bulletin 99: 432-442

Millar R B (1992). Estimating the size-selectivity of fishing gear by conditioning on the total catch. Journal of the American Statistical Association 87(420): 962968

Millar R B \& Holst R (1997). Estimation of gillnet and hook selectivity using loglinear models. ICES Journal of Marine Science 54: 471-477

Millar R B \& Fryer R J (1999). Estimating the sizeselection curves of towed gears, traps, nets and hooks. Reviews in Fish Biology and Fisheries 9: 89-116

Muller R G (2001). The 2000 Update of the Quota and Stock Assesment of Bluefish, Pomatomus saltatrix, on Florida's Atlanci Coast. Florida fish and Wildlife Conservation Commission. Florida Marine Research Institute pp. 24

Otway N M \& Craig J R (1993). Effects of hook size on the catches of undersized snapper Pagrus auratus. Marine Ecology Progress Series 93: 9-15 
Özdemir S, Erdem E, Özdemir Z B \& Şahin D (2009). Estimation of population parameters from lenght composition of pelagic species caught in the Black Sea: Horse mackerel (Trachurus trachurus), Bluefish (Pomatomus saltatrix) and Allis shad (Alosa alosa). Firat University Journal of Science 21: 1-8

Öztekin A, Özekinci U, Ayaz A, Cengiz Ö, Altınağaç U \& Aslan A (2014). The mouth opening-length relationship and the selectivity of bottom longline used for greater Forkbeard (Phycis blennoides B. 1768) fishing in Saros Bay (Northern Aegean Sea). Ege Journal Fisheries Aquatic Sciences 31(1): 41-45

Quinn T J \& Deriso R B (1999). Quantitative Fish Dynamics. Oxford University Press, New York, New York. pp. 542

Robillard E, Reis C S \& Jones C M (2009). Age-validation and growth of bluefish (Pomatomus saltatrix) along the East Coast of the United States. Fisheries Research 95: 65-75

Salerno D J, Burnett J \& Ibara R M (2001). Age, growth, maturity and spatial distribution of bluefish, Pomatomus saltatrix (Linnaeus), off the Northeast Coast of the United States, 1985-96. Journal of Northwest Atlantic Fishery Science 29: 31-39

Sigeal J \& Castellan N S (1989). Non parametric statistics for the behavioural sciences. Statistics Series, $2^{\text {nd }}$ Edition. Mc Graw Hill, New York

Sipe A M \& Chittenden M E Jr (2002). A comparison of calcified structures for ageing bluefish in the Chesapeake Bay region. Transactions of the American Fisheries Society 131: 783-790
Sousa F, Isidro E \& Erzini K (1999). Semi-pelagic longline selectivity for two demersal species from the azors: The black spot sea bream (Pegallus bogaraveo) and the bluemouth rockfish (Helicolenus dactylopterus dactylopterus). Fisheries Research 41: 25-35

Terceiro M \& Ross J L (1993). A comparison of alternative methods for the estimation of age from length data for Atlantic coast bluefish. Fishery Bulletin 91: 534-549

TFR (2012). Turkish Fisheries Regulations, Number 3/1(2012-65): 1-112

Ünsal A (2010). Boğaz'ın beş efendisi: Lüfer, palamut, levrek, tekir ve istavrite dair. Yapı Kredi Yayınları, No: 3230, 1. Bask1, İstanbul, Aralık, s. 191

Van der Elst R (1976). Gamefish of the east coast of southern Africa. 1. The biology of the elf, Pomatomus saltatrix (Linnaeus), in the coastal waters of Natal. Investigational Report Oceanographic Research Institute, South African Association of Marine Biological Research 44: 1-59

Wilk S J (1977). Biological and fisheries data on bluefish, Pomatomus saltatrix (Linnaeus), 56 pp, US National Marine Fisheries Service, Northeast Fisheries Science Center, Sandy Hook Laboratory Technical Series Report, 11

Woll A K, Boje J, Holst R \& Gundersen A C (2001). Catch rates and hook and bait selectivity in longline fishery for Greenland halibut at East Greenland. Fisheries Research 51: 237-246

Zengin (2013). An overview of the status of recreational fisheries in Turkey: Samples of Galata Bridge, the Dardanelles, and Lake Abant. Yunus Arastırma Bülteni 2013(2): 51-65 